\title{
A MULTI-PERSPECTIVE EXAMINATION OF EXPORT PROMOTION PROGRAMS: THE CASE OF PEIEX BY APEX-BRASIL
}

\begin{abstract}
The economic and social benefits of exports have been widely discussed in the literature. However, despite the reduction in export barriers and the consequent increase in international trade flows, many small and medium enterprises (SMEs) still do not sell their products abroad, often because they lack resources or expertise to successfully carry out export activities. Export promotion programs (EPPs) seek to assist SMEs in their efforts to compete abroad. The objective of this study is to examine a specific EPP - the PEIEx Program of APEX-Brasil - and identify benefits achieved and deficiencies of the program, according to multiples views. Semi-structured interviews with different actors (firms served by the program, managers of the promoting agency, instructors responsible for training and providing support to the firms, and the manager of an independent industry association) indicated that the program is, in general, satisfactory, but the results of the program seem to be contingent on proper selection of the profile of participating firms, alignment of their expectations about the scope of the program and sequential arrangement with other EPPs or competitiveness development programs. The study proposes some improvements to the PEIEx program as well as recommendations for investigating the impacts of EPPs.
\end{abstract}

Keywords: Export Promotion Programs. Export Assistance Programs. Exports. Small- And Medium-Sized Enterprises. Internationalization.

\section{AVALIAÇÃO MULIT-PERSPECTIVA DE PROGRAMAS DE APOIO À EXPORTAÇÃO: O CASO DO PEIEX DA APEX-BRASIL}

\section{RESUMO}

Os benefícios econômicos e sociais das exportações têm sido amplamente discutidos na literatura. No entanto, apesar da redução das barreiras à exportação e do consequente aumento dos fluxos de comércio internacional, muitas pequenas e médias empresas (PMEs) ainda não vendem seus produtos no exterior, muitas vezes por falta de recursos ou experiência para realizar com sucesso as atividades de exportação. Os programas de promoção de exportações (PPEs) buscam ajudar as PMEs em seus esforços para competir no exterior. O objetivo deste estudo é examinar um PPE específico - o Programa PEIEx da APEX-Brasil - e identificar os benefícios alcançados e as deficiências do programa, de acordo com múltiplos pontos de vista. Entrevistas semiestruturadas com diferentes atores (empresas atendidas pelo programa, gestores da agência de fomento, instrutores responsáveis pela formação e apoio às empresas e gestor de uma associação industrial independente) indicaram que o programa é, em geral, satisfatório, mas os resultados do programa parecem depender da seleção adequada do perfil das empresas participantes, do alinhamento de suas expectativas sobre o escopo do programa e do arranjo sequencial com outros PPEs ou programas de desenvolvimento de competitividade. O estudo propõe algumas melhorias para o programa PEIEx, bem como recomendações para investigar os impactos de PPEs.

Palavras-chave: Programas de Promoção à Exportação. Programas de Suporte à Exportação. Pequenas e Médias Empresas. Internacionalização. 


\section{EVALUACIÓN MULIT-PERSPECTIVA DE PROGRAMAS DE APOYO A LA EXPORTACIÓN: EL CASO DEL PEIEX DE APEX-BRASIL}

\section{RESUMEN}

Los beneficios económicos y sociales de las exportaciones se han discutido ampliamente en la literatura. Sin embargo, a pesar de la reducción de las barreras a la exportación y el consiguiente aumento de los flujos comerciales internacionales, muchas pequeñas y medianas empresas (PYME) aún no venden sus productos en el extranjero, a menudo porque carecen de recursos o experiencia para llevar a cabo actividades de exportación. Los programas de promoción de exportaciones (PPE) buscan ayudar a las PYMES en sus esfuerzos por competir en el exterior. El objetivo de este estudio es examinar un PPE específico, el Programa PEIEx de APEX-Brasil, e identificar los beneficios logrados y las deficiencias del programa, de acuerdo con las vistas múltiples. Entrevistas semiestructuradas con diferentes actores (empresas atendidas por el programa, gerentes de la agencia promotora, instructores responsables de la capacitación y apoyo a las empresas, y el gerente de una asociación industrial independiente) indicaron que el programa es, en general, satisfactorio, pero los resultados del programa parecen estar supeditados a la selección adecuada del perfil de las empresas participantes, la alineación de sus expectativas sobre el alcance del programa y el acuerdo secuencial con otros PPE o programas de desarrollo de la competitividad. El estudio propone algunas mejoras al programa PEIEx, así como recomendaciones para investigar los impactos de los PPE.

Palavras clave: Programas de Promoción a la Exportación. Programas de Apoyo a la Exportación. Pequeñas y Medianas Empresas. Internacionalización.

\footnotetext{
${ }^{1}$ Mestre em Administração de Empresas pela Pontifícia Universidade Católica do Rio de Janeiro - PUC/RJ. Brasil. Email: bettysadornelas@yahoo.com.br

${ }^{2}$ Doutor em Administração pela Universidade Federal do Rio de Janeiro - UFRJ. Professor Escola de Administração de Empresas de São Paulo da Fundação Getulio Vargas - EAESP/FGV. Brasil. E-mail: jtcarneiro@gmail.com
} 


\section{INTRODUCTION}

Exports represent a relevant proportion of world GDP (29.7\% in 2014, according to the World Bank, 2016). Particularly for small- and medium-sized enterprises (SMEs), exports are the main internationalization strategy (Leonidou, Katsikeas, Palihawadana \& Spyropoulou, 2007), since exports require relatively less resources, involve lower risks, and allow for greater flexibility (Cavusgil, Knight, Riesenberger, Rammal \& Rose, 2014). In fact, exports are the first stage in the establishment chain (Johanson \& Vahlne, 1977) for those firms that approach the international arena gradually.

However, exports entail barriers of several kinds: motivational, informational, operational/resource-based, and (lack of) knowledge (Wilkinson \& Brouthers, 2006). Small firms, in particular, tend to suffer from lack of information and of resources, which affect their ability to engage in exporting and to successfully continue the activity (Freixanet, 2012; Seringhaus \& Botschen, 1991).

Leonidou (2004) suggests that policy makers can help overcome both internal barriers (informational, functional, and marketing) and external barriers (procedural, governmental, and environmental) by providing educational, operational, and promotional assistance for firms. As argued by Tan, Brewer and Liesch (2007, p. 306), "[w]ithin the preinternationalisation phase, firms experience a learning process that is influential towards an initial internationalisation decision."

While there seems to be some general consensus that Export Promotion Programs (EPPs) bring benefits to firms (e.g., export readiness and competitiveness) and, in the aggregate, to their countries as well (Ayob \& Freixanet, 2014; Miocevic, 2013), the accumulated empirical findings about the impacts of EPPs have been somewhat inconclusive or even conflicting (Durmuşoğlu, Apfelthaler, Nayir, Alvarez \& Mughan., 2012; e.g., contrast the reported results in Diamantopoulos, Schlegelmilch \& Katy Tse, 1993; Francis \& Collins-Dodd, 2004; and Gençtürk \& Kotabe , 2001) and seem to suggest that different types of companies benefit differently from such programs (Czinkota \& Kotabe, 1992; Freixanet, 2012).

Such claims and conflicting findings point to the need of more in-depth examination of the mechanisms by which EPPs can enhance firms' export capabilities and of the contingencies that might affect the impacts. Among the four major categories of EPPs - information-, training-, trade mobility-, and financial aid-related programs (Leonidou, Palihawadana \& Theodosiou, 2011) - this study examines a particular type of training-oriented EPP, specifically the PEIEx program (Projeto Extensão Industrial Exportadora Exporting Industrial Extension Project, http://www.apexbrasil.com.br/qualifique-sua-empresa- peiex), led by APEX-Brasil (Brazilian Trade and Investment Promotion Agency, www.apexbrasil.com.br) - a free, by-invitation-only, program whose target is non-exporters or inexperienced exporters and whose objectives are to develop an export culture and to promote export readiness and competitiveness, but not necessarily to lead companies to achieve short-time market or financial results. Specifically, our research objective is to identify the (expected and actual) benefits and the deficiencies of an export promotion program (specifically, the PEIEx by APEX-Brasil), so as to generate recommendations to the promoting agency and the firms. A secondary objective is to unveil possible (environmental and firm-level) contingencies that might moderate the impact of export promotion programs.

With a focus on SMEs in the pre-export phase, this study sheds light on the mechanisms by which EPPs can enhance firms' export competitiveness, identifies some contingencies (moderating factors) that affect the effectiveness of EPPs, and uncovers negative aspects of such programs that might not have been dealt with in the literature. Therefore, this study addresses Leonidou et al. (2011) contentions about the need to pinpoint more precisely how EPPs shape firm's export behavior, the lack of theoretical foundation about the impacts of EPPs and the need to clarify the antecedents, mediators (and moderators, for that matter) and outcomes of EPPs. However, this study does not attempt to measure the effective short-term export results obtained by firms after having participated in the program.

This study helps to bring additional evidence regarding the impact of EPPs in emerging markets (an under-researched context, $c f$. Durmuşoğlu et al., 2012; and Williams, 2008) and, particularly, in a country (Brazil) with potential large domestic demand, given the size of its population and the recent rise of a large number of consumers to the middle class (Neri, 2012).

\section{LITERATURE REVIEW}

As claimed by Archer and Maser (1989), exports help boost national economies - and, as a consequence, increase tax proceeds, local employment and living standards -, create backward and forward linkages in the economy, and contribute to the national balance of payments; therefore, the promotion of exports is a top priority of many public policymakers.

Many small firms need outside help in order to overcome (external and internal) barriers to internationalization, which can be of a general nature (i.e., applicable to many firms in several countries) and also specific to regions and local market situations (Narayanan, 2015). Regional and industry specificities may demand particular, rather than generic, solution in 
order to promote exports (Kanda, Mejía-Dugand \& Hjelm, 2015). Therefore, governments and their agencies can play an important role by providing appropriate incentives and support, thereby inducing internationalization (Coelho \& Oliveira Junior, 2016).

Leonidou (1998) argues that firms seek exports when they perceive stimuli to do so, which can be of an internal or of an external nature. Internal stimuli can be proactive or reactive. Proactive internal stimulating factors can be, for example: search for scale economies, particular interest of managers, exploitation of distinctive product quality or other competitive advantages, and tapping potential sales. As for reactive internal stimulating factors, Leonidou (1998) mentions: sales compensation for seasonal products, decline of domestic sales and utilization of idle production capacity. External stimuli can also be of an internal or an external nature. External proactive stimulating factors can be, for example: official incentives, provision of information on foreign markets, export promotion/assistance programs, contacts deriving from participation in trade fairs or commercial missions. As for external reactive stimulating factors, there are: export initiation by domestic competitors, competitive pressures in the domestic market, and favorable exchange rate.

Durmuşoğlu et al., (2012) emphasize that EPPs represent an example of external (proactive) stimuli available to firms. Freixanet (2012) adds that there are several services, offered both through public and private initiatives, whose objective is to help firms overcome obstacles related to lack of motivation, capabilities and/or human or financial resources.

\section{Types of Export Promotion Programs (EPPs)}

There are seven major categories of export promotion/assistance programs ( $c f$. Diamantopoulos et al., 1993; Gençtürk \& Kotabe, 2001; Lederman, Olarreaga \& Payton, 2010; Seringhaus \& Botschen, 1991):

1. Export support services - exporter training, technical assistance, legal and regulatory support, support related to increased productivity, research and development and innovation as well as consultancy on strategic planning, export finance, pricing, logistics, customs, packaging and standardization of products, certification labels requirements, patent protection;

2. Market research and publication - trade fairs, exporter and importer missions, presentation of potential foreign buyers, follow-up services by foreign representatives abroad;

3. Marketing and commercial support information (at general, sector, and firm level), market surveys, online information on export markets, publications encouraging companies to export, exporter and importer contact database;

4. Country image building - advertising about the country, promotional events;

5. Financing - financial support both for the preshipment and post-shipment stages;

6. Tax incentives - suspension or elimination of taxes on imported materials for use in exported products;

7. Insurance - coverage of commercial, political, and extraordinary risks. services

In this study our focus is on (1) export support

\section{Alleged benefits of EPPs}

EPPs have been argued to provide benefits for the served companies and, in the aggregate, for their country.

Leonidou (2004) suggests that policymakers can help overcome both internal barriers (informational, functional, and marketing) and external barriers (procedural, governmental, and environmental) by providing educational, operational, and promotional assistance for firms. Besides, EPPs have an instrumental role (via information-related, education and training, and target marketing services) - which can help firms design and implement appropriate plans and strategies - and can promote an entrepreneurial behavior (i.e., risk tolerance, innovativeness, and proactiveness), thus inducing firms to tap international markets through exports (Leonidou, Samiee \& Geldres, 2015).

Supposedly, EPPs can help firms to increase their export activities by providing "specialized counseling and technical assistance on how to take advantage of business opportunities abroad, in general, and on how to access specific markets (e.g., conditions in terms of technical regulations, quality standards, etc.), in particular" (Martincus \& Carballo, 2010, p. 202) and offering access to objective knowledge ("informational materials on exporting, workshops and seminars on exporting, one-on-one export consultation, personal advice/consulting in home country, advice/consulting by state's promotion assistance offices in most important export country, international market research") and to experiential knowledge ("trade shows or catalogue show exhibitions, trade and sales lead development, trade missions, overseas promotion of the firm's services, export credit insurance, introduction to buyers / procurement officers in importing firms, export financing") (Durmuşoğlu et al., 2011, p.2).Singer and Czinkota (1994) argue that EPPs that offer managers personal experience are more effective than EPPs that are primarily informational.

Leonidou, Katsikeas and Piercy (1998) emphasize that an important benefit of EPPs is to stimulate interest in exports in the business community, by creating a more positive attitude among business 
managers to identify growth opportunities abroad and by minimizing the negative perceptions about the risks, costs and complexities associated with the export process. In addition, EPPs have been shown to increase export revenues and the probability of exporters' survival, particularly in times of crisis (Konings, Van Biesebroeck, \& Martincus, C., 2016).

Wilkinson and Brouthers (2006) suggest that the effectiveness of EPPs depends on the ability of companies to use them properly; in other words, EPPs would not contribute directly to export sales, but could improve the companies' competitive position. Likewise, Freixanet (2012) contends that EPPs "are expected to help companies become more competitive internationally, but the final achievement of exports depends on other variables beyond program control" (p.1077). In fact, EPPs can have a direct influence on export performance, but also an indirect influence, by means of the impact of EPPs on firm's export knowledge, and managers' perceptions about exports, which in turn can affect managerial commitment to exports, export strategy and export performance (Shamsuddoha \& Yunus, 2006).

On the other hand, the effects of EPPs may be temporary if the program does "not lead to the enhancements in product quality or sophistication which could have strengthened competitiveness durably" (Cadot, Fernandes, Gourdon \& Mattoo, 2015, p. 310).

Cavusgil and Yeoh (1994) contend that export assistance should not be restricted to export-willing firms, but rather "also should be strategically targeted at export-ready firms that have achieved export maturity - those with a solid management base, reliable product, sufficient sales experience, and adequate financial resources." (p. 82), but distinct emphases should compose the programs for each type of target group. In fact, other authors argue that firms in more advanced internationalization stages perceive or experience less usefulness in EPPs (Francis \& CollinsDodd, 2004; Czinkota, 1982).

\section{Contingent impacts of EPPs}

The impact of EPPs may vary across different profiles of firms, for example, across industry type, firm size or firm's export experience.

Industry. Kedia and Chhokar (1986) found that different industries (specifically, machine manufactures and food processors) had notably different perceptions about the factors that hinder the performance of their export business. The food processor industry considers knowledge on how to sell and price in foreign markets among the most important and more difficult issues in the export process, while machine manufactures see (lack of) knowledge on how to sell abroad, obtain information about customers and about overseas business practices as inhibiting factors of the export process.
Firm size. Larger companies tend to benefit less from support programs to export than smaller companies because the former have more resources and capabilities (Leonidou et al., 2011) and more access to information sources (Bonaccorsi, 1992). Oddly, Cadot, et al. (2015) found that only medium-sized firms, but not small or large firms, saw positive (albeit temporary) impacts from an EPP.

Firm's export experience. Hultman, Katsikeas and Robson (2011) argue that a given program may not fit the needs of every single firm; in fact, export experience (in terms of years devoted to the activity, the proportion of export revenues over total revenues, accumulated export sales or number of countries covered) can be a moderator of the impact of EPP on export performance. In a similar vein, Diamantopoulos et al. (1993) and Wilkinson and Brouthers (2000) argue that companies in different stages of exporting should be offered different support services, each appropriate to its stage. Companies with more export experience tend to need less export support programs than inexperienced companies, which face different barriers in their exporting activities (Martincus \& Caballo, 2010).

Accordingly, Leonidou et al. (2011) contend that the impact of EPPs (of an informational, educational/training, trade mobility or financial nature) on organizational resources and capabilities is greater for small firms than for large firms and for inexperienced exporters than for experienced exporters. Their findings provide empirical evidence about the moderating effect of firm size on the impact of export information-, education- and training-related programs, and trade mobility-related programs; and also, about the moderating effect of firm's export experience on the influence of information-related programs. However, they did not find significant differences among experienced and inexperienced exporters regarding the impact of education and training-related programs and trade mobility-related programs.

\section{Inconsistent findings across previous studies}

Despite the high number of studies on the impact of EPPs, Leonidou, Palihawadana, and Theodosiou (2011, p.3) contend that:

[...] research on national exportpromotion programs (1) is spread too thinly over many diverse areas, (2) lacks sufficient depth in analyzing the link between government assistance and the firm's export behavior, (3) suffers from the absence of solid theoretical platforms to provide justification for the interrelationships among constructs, (4) does not offer a clear view of the factors that have an antecedent, mediating, or outcome association with export-promotion 
programs, and (5) ignores other important parameters with a potentially useful role in explaining phenomena pertaining to government export assistance.

EPPs may bear different impacts on diverse export results. While Gençtürk and Kotabe (2001) concluded that EPPs affect mainly export diversification and profitability, rather than export sales, Francis and Collins-Dodd (2004) did not find a significant relationship of a given EPP with economic measures (although they found indirect benefits of EPPs). Similarly, Seringhaus (1984) did not find a relationship between a given program (trade missions) and export intensity or number of orders. Gençtürk and Kotabe (2001) found significant positive results regarding the firm's competitive position, but a nonsignificant result regarding export sales, while Martincus \& Carballo (2010) found a positive effect on export sales growth.

In fact, several studies, emplying varied assessment methods, have found positive but not significant effects of EPPs on export development or performance (e.g., Alvarez, 2004; Faroque \& Takahashi, 2015; Francis and Collins-Dodd, 2004; Geldres et al. 2011).

The type of EPP may also affect the results. Wilkinson and Brouthers (2000) found a positive effect of EPPs focusing on trade shows, but a negative impact of EPPs focusing on trade missions or market information activities.

In part, inconsistent findings may result from lack of control for endogeneity, in particular, selfselection bias and common causation. As argued by Martincus and Caballo (2010: 209), "managerial attitudes, qualification profile of personnel, and innovation capabilities [...] may play a role in determining both service usage and export performance." Besides, firms satisfied with previous use of some EPP are more likely to look for additional assistance (Martincus \& Caballo, 2010).

\section{PRESENTATION OF THE FOCAL EPP}

Apex-Brasil is a technical agency of MDIC (Ministério do Desenvolvimento, Indústria e Comércio Exterior - Ministry of Development, Industry and Foreign Trade). As reported on its website (ApexBrasil, 2016a),

The Brazilian Trade and Investment Promotion Agency (Apex-Brasil) works to promote Brazilian products and services abroad, and to attract foreign investment to strategic sectors of the Brazilian economy.

Apex-Brasil organizes several initiatives aiming to promote
Brazilian exports abroad. The Agency's efforts comprise trade and prospective missions, business rounds, support for the participation of Brazilian companies in major international trade fairs, arrangement of technical visits of foreign buyers and opinion makers to learn about the Brazilian productive structure, and other select activities designed to strengthen the country's branding abroad.

Apex-Brasil also plays a leading role in attracting foreign direct investment (FDI) to Brazil, by working to identify business opportunities, promoting strategic events and lending support to foreign investors willing to allocate resources in Brazil.

The agency offers several services: market intelligence, entrepreneurial training, internationalization strategies, business and image promotion, and investment attraction (Apex-Brasil, 2016a)

The specific export promotion program that is the focus of this study is called PEIEx (Projeto Extensão Industrial Exportadora - Exporting Industrial Extension Project. Its objective is to stimulate competitiveness and promote the export culture in companies (Apex-Brasil, 2016b). The program offers free diagnosis and proposed solutions. Its technical team offers training in the areas of strategic management, human capital, finance and costs, sales and marketing, product, manufacturing and trade.

\section{METHODS AND DATA}

As argued by, Flyvbjerg (2006: 242), “[g]ood social science is problem driven and not methodology driven", so that researchers should seek the methods that are most appropriate to provide an answer to the specific research question at hand. Given the existence of conflicting findings in the empirical literature about the impact of EPPs, we decided to examine the (expected and actual) benefits and the deficiencies of a specific category of export promotion programs; therefore, we chose to use a single-case (of one given EPP) and to conduct an in-depth investigation from the triangulation the views of multiple constituents. By means of 12 in-depth semi-structured interviews, we triangulated data from multiple perspectives, that is, multiple actors involved with one particular EPP (the PEIEx, led by Apex-Brasil):

- Export/competitiveness promoting entities

- two managers of the promoting agency itself (Apex-Brasil)

- two instructors hired by the agency to 


$$
\begin{aligned}
& \text { train the firms } \\
& \text { - one manager of an industry } \\
& \text { association that also promotes } \\
& \text { exports }
\end{aligned}
$$

- different types of firms

- five firms supported by the program for about two years (from different geographical nuclei of the program)

- one firm supported for just about one year

- one firm that declined to participate in the program

We collected spontaneous and stimulated responses about: the program objectives, the expectations and the results, potential contingencies that might affect the attainment of the program objectives, perceived weaknesses of the program and suggestions for improvement. Specifically, the semistructured interview script employed with the seven managers of firms (slightly adapted scripts were used to interview representatives of the promoting agency and of the industry association as well as the program instructors) covered an initial free account by the interviewee about the EPP, then some specific questions about potential moderators of the impact of EPPs, as suggested in the literature (firm size, industry, export experience, managerial commitment to exports, level of awareness and knowledge about EPPs, previous participation in capacity development programs, and international experience of firm's managers); in addition, the script addressed issues about expectations (support in planning, as well as financial, market and strategic results), results effectively attained (e.g., knowledge and capabilities, access to cheaper production factors, new product development etc.) the work of the program instructors (understanding about company's needs, diagnosis, problem identification and solution recommended, compliance with deadlines and other promises), level of overall satisfaction with the program and recommendations for improvement.

Some of the interviews were conducted in person, while some others were conducted through Skype or telephone. Interviews lasted for between 30 and 60 minutes and were taped and transcribed for later reference.

This research design was deemed appropriate to uncover detailed - and potentially contradictory information about the benefits and weaknesses of such type of EPP and the mechanisms by which such program can affect the export capacities and results of supported firms.

Two researchers independently read the transcriptions of the interviews in order to select evidence about the program objectives, the expectations and the results, potential contingencies that might affect the attainment of the objectives, perceived weaknesses of the program and suggestions for improvement. Then, together, the two researchers compared and contrasted the views of each type of informant (those related to the EPP-promoting entity, those related to the firms, and the one related to an industry association) and also checked those views against the academic literature.

As limitations of the method, one should note that all the firms were indicated by the EPP agency itself, which entails the potential risk of social desirability bias (however, as a way to minimize this risk, we promised the firms that their specific responses would not be identified with the firm's name; besides, we included the independent view of the industry association) and the potential inadvertent interference of the interviewer in the responses. While we partially addressed Piekkari, Welch and Paavilainen's (2008: 589) recommendation to employ "variety of data sources used per case" in an effort not to fall into the trap of "increasing the number of cases [...] at the expense of variety and depth in data sources", we employed only one data collection method (i.e., personal interviews), but did not cover additional types of data sources (e.g., competitors) or data collection methods (e.g., companies' and agency's reports).

Although the findings cannot be generalized to the population of EPPs or to the population of firms supported by the PEIEx program, it is possible to derive contributions to theory and to methods (i.e., precaution on conducting research about EPPs) as well as practical recommendations to managers of the program and to supported firms.

\section{RESULTS}

\section{Expectations towards and benefits of the program}

One of the EPP instructors said that "the program changes the cognitive map of the entrepreneurs, by turning data into information, information into knowledge and knowledge into wisdom." The instructors informed that some firms had higher expectations (e.g., duration of the training effort, referral to foreign customers, and access to funding sources) than those that the program purported to deliver. However, the manager of the industry association complained that she had "low expectations regarding the program, due to problems reported by companies in previous editions." As for firms served by the program more than two years ago, expectations varied according to their level of business maturity: less structured firms expected training, strategic diagnosis, new market information, contacts and sales to overseas customers, and support in the stages of preparation and implementation of exports; while more structured firms expected training, support in the preparation stage for exporting, validation of existing business models, and recommendations regarding process improvements on how to export. None of the 
firms expressed expectations related to direct financial outcomes. The firm recently (less than one year) served by the program claimed to expect knowledge about the export process, preparation to face difficulties, support to initiate the first export, and $10 \%-20 \%$ revenue increase due to exports. As for the firm that declined the invitation to join the program, its manager argued that they were already a very experienced exporter (over 30 years), so that the firm would not benefit from the (basic) training that the program offers.

\section{Actual outcomes of the program}

The managers of the PEIEx program stated that their methodology (based on theme training and exchange of experiences among peer companies) indeed helps firms obtain learning about strategies, processes, management practices and management processes, as well as increased competitiveness and level of maturity in management, staff, and appropriate processes to internationalize. The instructors also agree that the program helps companies learn about strategies, management practices and management processes. One of the instructors contended though, "the program is quite useful in preparation and planning for export; however, not as much in the implementation and operation phases." The representative of the industry association maintains that "managers who join the program build expectations that they will export, but when such expectations are not confirmed, huge frustration appears." She adds, "Companies need a management shock before they start thinking of exporting." She concludes that actual exports should be a medium/long-term objective because "a negative experience creates a [mental] blockage and difficulty for the next program," since "the entrepreneur becomes increasingly resistant."

The managers of the firms that were assisted more than two years back agree that the acquisition of new knowledge is the main strength of the program. In the words of one of them, "participation in PEIEX project changes the way of thinking of the businessperson, who becomes more strategic and more confident in his ability to export." In general, they agree on the main benefits attained: support in the preparation, review of strategic planning and validation of business models, suggestion of new products; also, support in adaptation of process, documentation, products, packaging, labels, price positioning, technical materials, and commercial materials such as the website and brochures. Besides, these managers said that they received recommendations for participation in other export promotion programs such as trade missions and industry projects, with full technical support and infrastructure. Interestingly, one of the managers contended that "the results depend largely on the company and it is necessary to accept suggestions and put them into action." The manager of the recently assisted firm said that it was still early to talk about results, but they were satisfied.

One of the program instructors noted that, in very small companies, managers/founders may be so involved in daily operations that they may not find time to think about exporting and to attend the training sessions.

\section{Recommendations for improvement}

One of the agency managers said that the program should evolve its focus from exports into internationalization; in his words, "from export readiness to internationalization readiness." $\mathrm{He}$ illustrates his reasoning by saying that firms should enter global value chains, "from [manufacturing and exporting] the shoe sole, [then] the unbranded shoe, [to] the branded shoe and the shoe design." He adds that "the major challenge of the program is the development of methodology in order to meet not only the classic industry, but also the service sector, the creative industry and the new economy." As further improvements to the program, the agency managers mentioned the need for heterogeneous composition of the technical teams, the mandatory presence of at least one foreign trade expert, changes in the selection of companies attended, and automation of the paperwork.

One of the instructors said that, given the comprehensiveness and the complexity of the methodology of the program, there should be careful capacitation of future instructors, since the knowledge transfer process is long. Besides, he added that real cases should be used and that a team of experts (instead of some "overall" instructor) should be hired. The other instructor recommended that the performance metrics be reassessed and that a longer period be considered to measure the results.

The industry association manager was emphatic about the need to calibrate expectations from the very beginning and to employ a foreign trade expert. Besides, she maintained that regional specificities should be considered, instead of national formulas. She reinforced the importance of follow-up programs, either by the promoting agency itself or by other entities whose mission is also to increase companies' competitiveness.

Although managers stated to be satisfied with the program, they also identified opportunities for improvement. In particular, they recommended that an expert in foreign trade be included in the team. In general, they want a longer program with a closer eye ("closer before, during, and after exports"), and would like to receive suggestions on how to prioritize target countries. One of the managers said that firms want "to be guided". 


\section{ANALYSIS AND RECOMMENDATIONS}

The triangulation of views brings a more nuanced picture of the EPP phenomenon. The reported expectations varied across firms with different levels of managerial expertise and of export knowledge. Less structured companies (in terms of management and experience with the export process) presented higher expectations than those promised by the promoting agency, especially regarding sales to overseas customers and support in the preparation and implementation of exports. Interestingly the recently supported firm had higher expectations regarding financial outcomes (specifically, revenue increase from exports) than firms that had been supported by the program longer before. Such high a priori expectations may lead to disappointment with results attained; thereby, the promoting agency has to calibrate carefully the expectations of the firms; besides, researchers are well-advised not to immediately compare "export satisfaction" results (in particular, volumes and revenues) across firms at rather different stages along the program. Frustration with the results (even if the firms themselves are somehow "to blame") may jeopardize future efforts to stimulate exports - both for the affected firms and for others that have heard about the disappointing results.

On the other hand, better structured firms expressed perceptions which are more in line with the opinions of the agency managers. However, there is great controversy between the views of the EPP agency and that of the industry association. Such divergence suggests that the program should count on some independent assessment.

The effective achievement of results depends on the commitment that firms demonstrate to exporting and also on their (ex-ante) management and operational prowess (as pointed out by the representative of the industry association) and the subsequent participation in follow-up programs (e.g., trade missions).

The selection process can be improved, since one of the invited companies was already an experienced exporter, that is, did not belong to the target public.

The empirical evidence from this study makes it clear that EPPs should not be conceptualized as a one-size-fits all framework. In fact, several contingencies seem to affect the attainment of the objectives of the program: size of the firms, type of industry, level of previous experience with exports, managers' commitment, managers' (personal or professional) international experience, and firm's managerial and operational expertise. Consequently, the objectives should be customized according to the particular type of firm(s) to be supported (e.g., experienced vs. inexperienced exporters).

A comparison of our findings with the literature brings some insights. First, engaging firms in sequential and complementary programs tends to improve the results achieved (Martincus \& Carballo, 2010). Also, the effectiveness of the program seems to depend on the appropriate employment of support services that should fit the specific export stage of firms (Diamantopoulos et al., 1993; Hultman et al., 2011; Wilkinson \& Brouthers, 2000).

In agreement with Seringhaus \& Botschen's (1991) recommendation to hear what firms have to say, our findings suggest that the export agency has much to gain from interacting closer with firms.

This study allows us to extract practical recommendations for the EPP agency, such as:

- Improve the selection process of target companies

- Align the expectations of the participating companies

- Hire expert instructors, including a foreign trade specialist

- Include complementary programs (which may demand cooperation between exportpromoting agencies)

- Develop the methodology in order to include additional industries other than just manufacturing

- Foster the exchange of experiences among the firms

- Enlarge the time horizon to measure the results

Some academic recommendations for future studies about the impact of EPPs follow:

- Match the measures of export performance with the objectives of the EPP

- Carefully measure the absolute results attained versus the level of satisfaction (reported by both the promoting agency and the firms), since satisfaction depends on the interplay between absolute results and ex-ante expectations

- Sophisticate the explanatory models by including moderators (e.g. company international experience) or using more homogenous groups of firms

-Work with sub-samples - e.g., firms satisfied with previous programs, firms disappointed with previous programs, and firms without experience in EPPs

- Control for endogenous effects, both by employing appropriate ex-ante research design (e.g., propensity score matching, in order to account for self-selection bias) and running ex-post tests

- Investigate the compound impact of participation in sequential and complementary programs. 
A Multi-perspective Examination of Export Promotion Programs: The Case of PEIEx by APEX-Brasil

\section{CONCLUSIONS}

This study contributed to the literature on the impacts of EPPs by providing evidence from distinct and complementary viewpoints. Such triangulation shed light on the potentially conflicting impacts of such programs and on possible moderators of their effect. Whereas most of the studies on the theme have been conducted in developed markets (cf. Durmuşoğlu et al., 2012; Martincus \& Carballo, 2008), ours focuses on an emerging market - a context of weaker institutions (Cuervo-Cazurra \& Ramamurti, 2014; Meyer \& Peng, 2015), which tends to affect export potential because of deficiencies in legal/regulatory frameworks and in infrastructure (energy, transportation, telecommunications), undeveloped capital markets, lack of effective industrial policies and lack of talented workforce.

In terms of practical recommendations, this study brought evidence of the overall adequacy of the PEIEx program, but also indicated several points that need attention from the promoting agency, in particular: improvement in the selection of firms, calibration of expectations, need to articulate sequential EPPs and other programs devoted to enhancing SMEs' competitiveness, need to bring instructors who possess specialized (rather than just general) knowledge about specific export processes.

As for academic contributions, we highlighted the need to control for endogeneity (particularly, selfselection bias and common causation) in the studies about the impacts of EPPs and the need to include moderating effects (e.g., firm size, export experience, industry).

\section{REFERENCES}

Alvarez, R. (2004). Sources of export success in smalland medium-sized enterprises: the impact of public programs, International Business Review, 13(3), 383400.

Apex-Brasil (2016a). Who We Are. Retrieved from:http://www.apexbrasil.com.br/en/who-we-are. Access on 02-May-2016.

Apex-Brasil (2016b). Qualifique a sua empresa [Qualifyyourcomapny]. Retrieved from: http://www.apexbrasil.com.br/qualifique-sua-empresapeiex. Access on 02-May-2016.

Archer, S. H., \& Maser, S. M. (1989). State Export Promotion for Economic Development. Economic Development Quarterly, 3 (3), 235-242.

Ayob, A. H., \& Freixanet, J. (2014). Insights into public export promotion programs in an emerging economy: The case of Malaysian SMEs. Evaluation and program planning, 46, 38-46.

Bonaccorsi, A. (1992). On the Relationship between Firm Size and Export Intensity. Journal of International Business Studies, 23 (4), 605-35

Cadot, O., Fernandes, A. M., Gourdon, J., \& Mattoo, A. (2015). Are the benefits of export support durable? Evidence from Tunisia. Journal of International Economics, 97(2), 310-324.

Cavusgil, S. T., Knight, G., Riesenberger, J. R., Rammal, H. G., \& Rose, E. L. (2014). International Business. Pearson Australia.

Cavusgil, S. T., \& Yeoh, P. L. (1994). Public sector promotion of US export activity: a review and directions for the future. Journal of Public Policy \& Marketing, 13(1): 76-84.

Coelho, D. B. \& Oliveira Junior, M. M. (2016). Internationalization of companies in the contemporary government development agenda: critical and analytical reflections for international business. $\mathrm{Cad}$. EBAPE.BR [online], 14 (special issue), 527-550.

Cuervo-Cazurra, A., \& Ramamurti, R. (2014). Conclusion: An Agenda for EMNC Research. In Cuervo-Cazurra, A., \& Ramamurti, R. (Eds.). Understanding multinationals from emerging markets. Cambridge University Press.

Czinkota, M. R. (1982). An evaluation of the effectiveness of US export promotion efforts. Export policy: A global assessment, 63-71.

Czinkota, M. R., \& Kotabe, M. (1992). State government promotion of manufacturing exports: A gap analysis. Journal of International Business Studies, 23(4), 637-658.

Diamantopoulos, A., Schlegelmilch, B. B., \& KatyTse, K. Y. (1993). Understanding the role of export marketing assistance: empirical evidence and research needs. European Journal of Marketing, 27(4), 5-18.

Durmuşoğlu, S. S., Apfelthaler, G., Nayir, D. Z., Alvarez, R., \& Mughan, T. (2012). The effect of government-designed export promotion service use on small and medium-sized enterprise goal achievement: A multidimensional view of export performance. Industrial Marketing Management, 41(4), 680-691.

Faroque, A. R. and Takahashi, Y. (2015). Export marketing assistance and born global performance: does export commitment matter? Asia Pacific Journal of Marketing and Logistics, 27(3), 421-443. 
Flyvbjerg, B. (2006). Five misunderstandings about case-study research. Qualitative Inquiry, 12(2), 219245.

Francis, J., \& Collins-Dodd, C. (2004). Impact of export promotion programs on firm competencies, strategies and performance - The case of Canadian high-tech SMEs. International Marketing Review, 4(5), 474-495.

Freixanet, J. (2012). Export promotion programs: Their impact on companies' internationalization performance and competitiveness. International Business Review, 21(6), 1065-1086.

Geldres, V. V., Etchebarne, M. S. \& Bustos, L. H. (2011) Promoción de Exportaciones en el Ambito Público: Su impacto en el Desempeño Exportador a Nivel de la Firma, Academia Revista Latinoamericana de Administración, 47, 1-17.

Gençtürk, E. F., \& Kotabe, M. (2001). The effect of export assistance program usage on export performance. Journal of International Marketing, 9(2), 51-72.

Hultman, M., Katsikeas, C. S., \& Robson, M. J. (2011). Export promotion strategy and performance: the role of international experience. Journal of International Marketing, 19(4): 17-39.

Johanson, J., \& Vahlne, J. E. (1977). The internationalization process of the firm: A model of knowledge development and increasing foreign market commitments. Journal of International Business Studies, 8(1): 23-32.

Kanda, W., Mejía-Dugand, S., \& Hjelm, O. (2015). Governmental export promotion initiatives: awareness, participation, and perceived effectiveness among Swedish environmental technology firms. Journal of Cleaner Production, 98, 222-228.

Kedia, B., \& Chhokar, J. (1986). Factors inhibiting export performance of firms: an empirical investigation. Management International Review, 26(4): 33-43.

Konings, J., Van Biesebroeck, J., \& Martincus, C. V. (2016). Did export promotion help firms weather the crisis?. Economic Policy, 31(8): 653-702

Lederman, D., Olarreaga, M., \& Payton, L. (2010). Export promotion agencies: Do they work?. Journal of development economics, 91(2): 257-265.

Leonidou, L. C. (2004). An analysis of the barriers hindering small business export development. Journal of small business management, 42(3), 279-302.
Leonidou, L. C. (1998). Factors stimulating export business: an empirical investigation. Journal of Applied Business Research, 14(2): 43-68.

Leonidou, L. C., Katsikeas, C. S., Palihawadana, D., \& Spyropoulou, S. (2007). An analytical review of the factors stimulating smaller firms to export: Implications for policy-makers. International Marketing Review, 24(6), 735-770.

Leonidou, L. C., Katsikeas, C. S., \& Piercy, N. F. (1998). Identifying managerial influences on exporting: past research and future directions. Journal of International Marketing, 6(2): 74-102.

Leonidou, L. C., Samiee, S., \& Geldres, V. V. (2015). Using National Export Promotion Programs to Assist Smaller Firm's International Entrepreneurial Initiatives. Handbook of Research on International Entrepreneurship Strategy: Improving SME Performance Globally, 239-252.

Leonidou, L. C., Palihawadana, D., \& Theodosiou, M. (2011). National export-promotion programs as drivers of organizational resources and capabilities: effects on strategy, competitive advantage, and performance. Journal of International Marketing, 19(2), 1-29.

Martincus, C. V., \& Carballo, J. (2010). Beyond the average effects: The distributional impacts of export promotion programs in developing countries. Journal of Development Economics, 92(2): 201-214.

Martincus, C. V., \& Carballo, J. (2008). Is export promotion effective in developing countries? Firmlevel evidence on the intensive and the extensive margins of exports. Journal of International Economics, 76(1), 89-106.

Meyer, K. E., \& Peng, M. W. (2015). Theoretical foundations of emerging economy business research. Journal of International Business Studies, 47(1), 3-22.

Miocevic, D. (2013). Exploring export promotion policy from a justice perspective: A case study. Journal of Macromarketing, 26.

Narayanan, V. (2015). Export Barriers for Small and Medium-sized Enterprises: A Literature Review based on Leonidou's Model. Entrepreneurial Business and Economics Review, 3(2), 105-123.

Neri, M. (2012). A Nova Classe Média: O Lado Brilhante da Pirâmide [The New Middle Class: The Brilliant Side of the Pyramid], Rio de Janeiro: Saraiva.

Piekkari, R., Welch, C., \& Paavilainen, E. (2008). The case study as disciplinary convention: Evidence from international business journals. Organizational 
Research Methods, 12, 567-589.

Seringhaus, F. H. R. (1984). Government export marketing assistance \& medium-sized Ontario manufacturing firms: The role \& impact of trade missions on firms off-shore market involvement. $\mathrm{PhD}$ dissertation. York University, Toronto.

Seringhaus, F. R., \& Botschen, G. (1991). Crossnational comparison of export promotion services: the views of Canadian and Austrian companies. Journal of International Business Studies, 115-133.

Shamsuddoha, A. K., \& Yunus Ali, M. (2006). Mediated effects of export promotion programs on firm export performance. Asia Pacific Journal of Marketing and Logistics, 18(2), 93-110.

Singer, T. O., \& Czinkota, M. R. (1994). Factors associated with effective use of export assistance. Journal of International Marketing, 2(1): 53-71.
Tan, A., Brewer, P., \& Liesch, P. (2007). Before the first export decision: Internationalisation readiness in the pre-export phase. International Business Review, 16, 294-309.

Williams, D. (2008). Export stimulation of micro- and small locally owned firms from emerging environments: New evidence. Journal of International Entrepreneurship, 6:101-122

Wilkinson, T., \& Brouthers, L. E. (2006). Trade promotion and SME export performance. International Business Review, 15(3), 233-252.

Wilkinson, T. J., \& Brouthers, L. E. (2000). An evaluation of state sponsored promotion programs. Journal of Business Research, 47(3), 229-236.

World Bank (2016). Exports of Goods and Services (\% of GDP). Retrieved from: http://data.worldbank.org/indicator/NE.EXP.GNFS.ZS/ countries/1W?display=graph. Access: 02-May-2016. 